\title{
Photophysical and Electrochemical Studies of Multinuclear Complexes of Iron(II) with Acetate and Extended Conjugated N-Donor Ligands
}

\author{
Norbani Abdullah, ${ }^{1}$ Suhana Mohd Said, ${ }^{2}$ Anita Marlina, ${ }^{1}$ Muhamad Faris Roslan, ${ }^{2}$ \\ Afiq Azil, ${ }^{1}$ and Abdul Rahman Nordin ${ }^{1}$ \\ ${ }^{1}$ Department of Chemistry, Faculty of Science, University of Malaya, 50603 Kuala Lumpur, Malaysia \\ ${ }^{2}$ Department of Electrical Engineering, Faculty of Engineering, University of Malaya, 50603 Kuala Lumpur, Malaysia \\ Correspondence should be addressed to Norbani Abdullah; norbania@um.edu.my
}

Received 21 May 2014; Revised 8 August 2014; Accepted 9 August 2014

Academic Editor: Hua Bai

Copyright ( $) 2015$ Norbani Abdullah et al. This is an open access article distributed under the Creative Commons Attribution License, which permits unrestricted use, distribution, and reproduction in any medium, provided the original work is properly cited.

\begin{abstract}
A dimeric iron(II) complex, trans- $\left[\mathrm{Fe}_{2}\left(\mathrm{CH}_{3} \mathrm{COO}\right)_{4}(\mathrm{~L} 1)_{2}\right](\mathbf{1})$, and a trinuclear iron(II) complex, $\left[\mathrm{Fe}_{3}\left(\mathrm{CH}_{3} \mathrm{COO}\right)_{4}\left(\mathrm{H}_{2} \mathrm{O}\right)_{4}(\mathrm{~L} 2)\right](2)$, were studied as potential dye-sensitised solar cell materials. The structures of both complexes were deduced by a combination of instrumental analyses and molecular modelling. Variable-temperature magnetic susceptibility data suggested that $\mathbf{1}$ was made up of $56.8 \%$ high-spin (HS) and $43.2 \%$ low-spin (LS) Fe(II) atoms at $294 \mathrm{~K}$ and has a moderate antiferromagnetic interaction $(J=$ $-81.2 \mathrm{~cm}^{-1}$ ) between the two $\mathrm{Fe}$ (II) centres, while 2 was made up of $27.7 \% \mathrm{HS}$ and $72.3 \% \mathrm{LS} \mathrm{Fe}$ (II) atoms at $300 \mathrm{~K}$. The optical band gaps $\left(E_{o}\right)$ for 1 were $1.9 \mathrm{eV}$ (from absorption spectrum) and $2.2 \mathrm{eV}$ (from fluorescence spectrum), electrochemical bandgap $\left(E_{e}\right)$ was $0.83 \mathrm{eV}$, excited state lifetime $(\tau)$ was $0.67 \mathrm{~ns}$, and formal redox potential $\left(E^{\prime}\left(\mathrm{Fe}^{\mathrm{III}} / \mathrm{Fe}^{\mathrm{II}}\right)\right)$ was $+0.63 \mathrm{~V}$. The corresponding values for 2 were $3.5 \mathrm{eV}$ (from absorption spectrum), $1.8 \mathrm{eV}$ (from fluorescence spectrum), $0.69 \mathrm{eV}, 2.8 \mathrm{~ns}$, and $+0.41 \mathrm{~V}$.
\end{abstract}

\section{Introduction}

Polypyridyl complexes of $\mathrm{Fe}(\mathrm{II})$ are currently attracting the attention of researchers as potential photosensitizers in dyesensitized solar cells (DSSC) [1-3]. These low-spin complexes have similar structures as the corresponding $\mathrm{Ru}(\mathrm{II})$ complexes [4-9] but are much cheaper, easier to prepare, and less toxic.

We noted that the $\mathrm{Fe}(\mathrm{II})$ complexes reported as potential DSSC materials were mostly mononuclear. Hence, we focused our research on multinuclear Fe(II) complexes, especially involving $\pi$-conjugated ligands, as they are expected to have better photosensitization (especially absorption of lower photonic energy) and redox properties.

This paper reports the syntheses, structural deduction, and determinations of band gaps and excited state lifetimes of a dimeric iron(II) complex, trans$\left[\mathrm{Fe}_{2}\left(\mathrm{CH}_{3} \mathrm{COO}\right)_{4}(\mathrm{Ll})_{2}\right]$ (1) and a trinuclear iron(II) complex, $\left[\mathrm{Fe}_{3}\left(\mathrm{CH}_{3} \mathrm{COO}\right)_{4}\left(\mathrm{H}_{2} \mathrm{O}\right)_{4}(\mathrm{~L} 2)\right]$ (2) (Figure 1). L1 $\left(4,4^{\prime}\right.$-bis $[3,4-$ bis(tetradecyloxy)styryl]-2,2' -bipyridine) was a bidentate
$\mathrm{N}_{2}$-bipyridyl donor, while L2 was a multidentate $\mathrm{N}$-donor dianion of a Schiff base, 6-phenyl- $N, N^{\prime}$-bis-(1H-pyrrol-2ylmethylene)-[1,3,5]-triazine-2,4-diamine. The magnetic data of both complexes are also presented to establish the spin states of the $\mathrm{Fe}$ (II) centres. The main objective of this paper was to establish a correlation between band gaps and excited state lifetimes with the nuclearity and spin states of a complex, and types of conjugated ligands $\left(2,2^{\prime}\right.$-bipyridine versus Schiff base).

\section{Experimental Results}

3,4-Bis(tetradecyloxy)benzaldehyde was a gift from Professor D. W. Bruce from the Department of Chemistry, University of York, United Kingdom. Other chemicals were commercially available and used as received. The elemental analyses (C, $\mathrm{H}, \mathrm{N}$ ) were carried out on a Thermo Finnigan Flash EA 1112. The ${ }^{1} \mathrm{H}-\mathrm{NMR}$ spectrum was recorded on a JEOL FTNMR lambda $400 \mathrm{MHz}$ spectrometer. The FTIR spectra were 


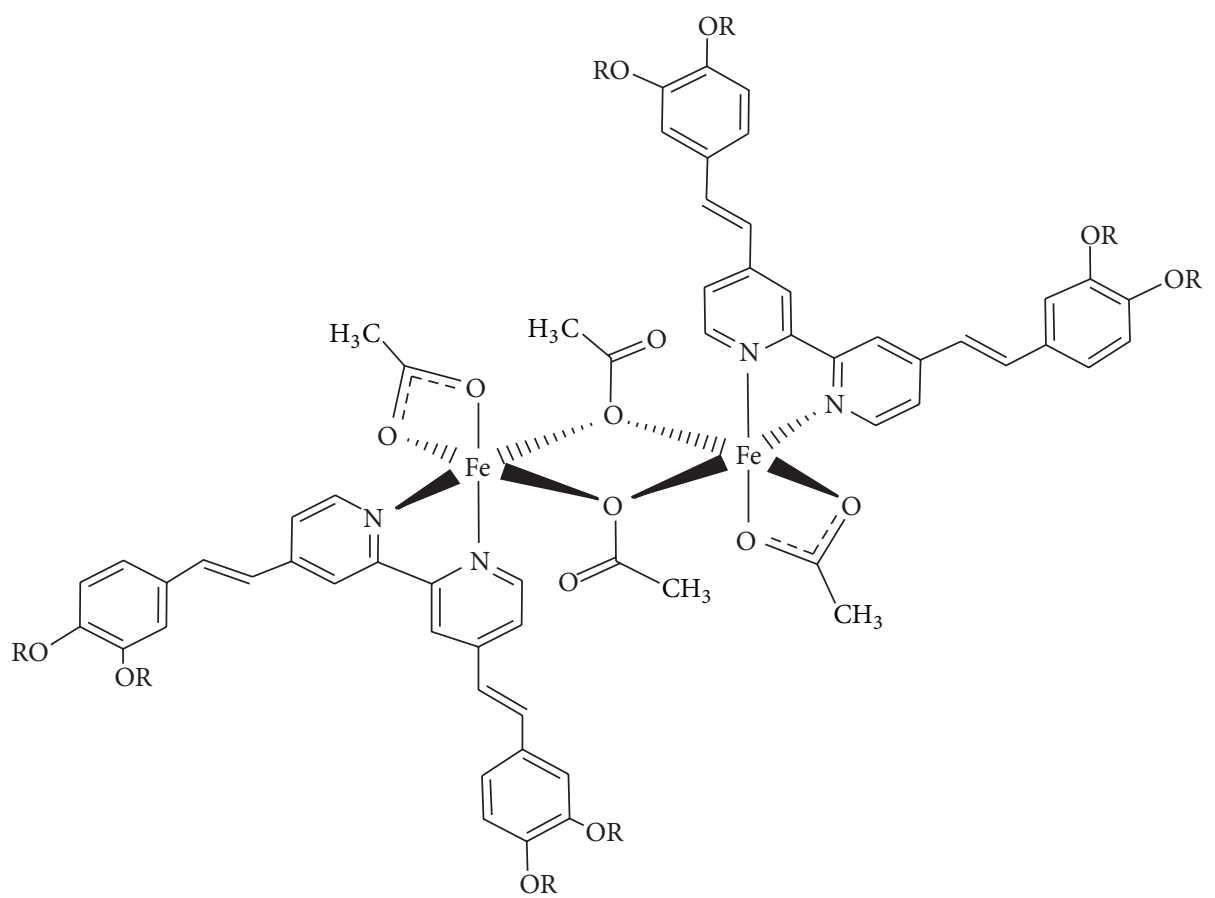

(a)

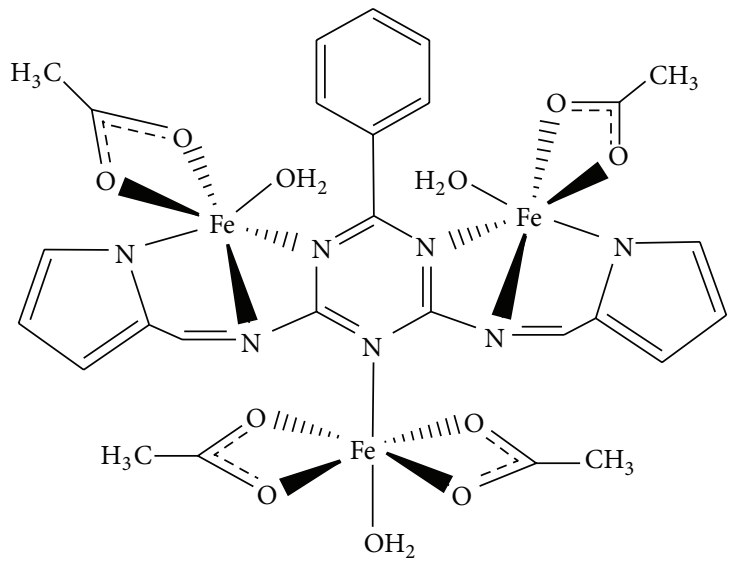

(b)

Figure 1: Proposed structures of (a) $\mathbf{1}\left(\mathrm{R}=\mathrm{CH}_{3}\left(\mathrm{CH}_{2}\right)_{13}\right.$ and (b) 2.

recorded for neat samples from $4000 \mathrm{~cm}^{-1}$ to $450 \mathrm{~cm}^{-1}$ on a Perkin-Elmer Frontier FTIR spectrometer equipped with a diamond attenuated total reflectance attachment. The UVVis spectra were recorded from $1000 \mathrm{~nm}$ to $400 \mathrm{~nm}$ on a Shimadzu UV-Vis-NIR 3600 spectrophotometer. The lowtemperature magnetic susceptibilities were measured on a Quantum Design MPMS XL EverCool SQUID magnetometer at 1 Tesla and temperature range $300-2 \mathrm{~K}$. The raw data was analysed using Microsoft Excel and IGOR Pro. The excitation and emission photoluminescence spectra were recorded on a PTI QuantaMaster 40 spectrofluorometer. The slit widths were set at a resolution of $10 \mathrm{~nm}$ for excitation and $5 \mathrm{~nm}$ for emission. The fluorescence life time measurement was performed on a PTI TimeMaster (TM200) LED-based Strobe Lifetime spectrofluorometer using the stroboscopic technique. The observed fluorescence decay was analyzed using PTI Felix GX data acquisition and analysis software. Data was recorded in 100 ps time intervals from $50 \mathrm{~ns}$ to $70 \mathrm{~ns}$ observation window. The instrument response function was measured from the scattered light and estimated to be about $1.5 \mathrm{~ns}$ (full width at half maximum). The measured transients were fitted to multiexponential functions convoluted with the system response function. The fitting procedure was based on the Marquardt algorithm, where the experimental data were compared to a model decay convoluted with the IRF. The fit was judged by the value of the reduced $\chi^{2}$. The cyclic voltammetric scans (CV) were recorded on a Gamry Instrument Reference 600 potentiostat/galvanostat/ZRA. The electrolyte was tetrabutylammonium tetrafluoroborate (TBATFB) $(0.05 \mathrm{M})$, working 
electrode was glassy carbon, reference electrode was saturated calomel, and counter electrode was platinum wire. The initial and final voltages were $0 \mathrm{~V}$, the potential range was $+1.5 \mathrm{~V}$ to $-1.5 \mathrm{~V}$, and the scan rate was $100 \mathrm{mV} \mathrm{s}^{-1}$. The molarities of the samples were $0.005 \mathrm{M}$, and $\mathrm{N}_{2}$ was bubbled through the solutions prior to analyses.

\subsection{Syntheses}

2.1.1. [3,4-Bis(tetradecyloxy) benzylidene] aniline. Aniline $(1.08 \mathrm{~g}, 11.7 \mathrm{mmol})$ was added to a magnetically stirred hot ethanolic solution $\left(75 \mathrm{~cm}^{3}\right)$ of 3,4-bis(tetradecyloxy)benzaldehyde $(5.02 \mathrm{~g}, 9.45 \mathrm{mmol})$, followed by a few crystals of $p$-toluenesulfonic acid. The reaction mixture was cooled to room temperature and left stirring overnight. The solvent was removed under reduced pressure, and the powder obtained was filtered and washed with ethanol. The yield was $5.6 \mathrm{~g}(98 \%)$.

2.1.2. L1. [3,4-Bis(tetradecyloxy)benzylidene]aniline (5.00 g, $8.25 \mathrm{mmol})$ was dissolved in $\operatorname{DMF}\left(50 \mathrm{~cm}^{3}\right)$ by heating at $50^{\circ} \mathrm{C} .4,4^{\prime}$-Dimethyl-2, $2^{\prime}$-bipyridine $(0.76 \mathrm{~g}, 4.12 \mathrm{mmol})$ was added to the hot solution, and the reaction mixture was flushed with nitrogen. Potassium $t$-butoxide (4.04 g, $36.0 \mathrm{mmol}$ ) was added portionwise, and the reaction mixture was flushed again with nitrogen, heated to $80^{\circ} \mathrm{C}$, and left stirring at this temperature for about $3 \mathrm{~h}$. Hydrochloric acid $(10 \%)$ was added to the cooled mixture until $\mathrm{pH} 7$, followed by distilled water $\left(200 \mathrm{~cm}^{3}\right)$ and dichloromethane $\left(300 \mathrm{~cm}^{3}\right)$. The organic layer was washed with saturated sodium bicarbonate $\left(200 \mathrm{~cm}^{3}\right)$ and then with distilled water $\left(200 \mathrm{~cm}^{3}\right)$. It was dried over anhydrous sodium sulphate, and the solvent was removed under reduced pressure. The yield was $4.8 \mathrm{~g}(97 \%) .{ }^{1} \mathrm{H}-\mathrm{NMR}\left(400 \mathrm{MHz}, \mathrm{CDCl}_{3}, \delta / \mathrm{ppm}\right): 0.88$ $(t, 12 \mathrm{H}), 1.26-1.60(m, 88 \mathrm{H}), 1.85(m, 8 \mathrm{H}), 4.1(m, 8 \mathrm{H}), 6.91$ $(d, 2 \mathrm{H} ; J=12 \mathrm{~Hz}), 7.27(d, 2 \mathrm{H} ; J=12 \mathrm{~Hz}), 7.31(d, 2 \mathrm{H}), 7.58$ $(s, 2 \mathrm{H}), 8.22(s, 2 \mathrm{H}), 8.34(s, 2 \mathrm{H}), 7.53(d, 2 \mathrm{H})$, and $8.53(d$, $2 \mathrm{H})$. Selected IR bands $\left(\bar{v} / \mathrm{cm}^{-1}\right)$ were $2917 \mathrm{vs}, 2850 \mathrm{vs}, 1589 \mathrm{~s}$, 1576 s, 1512 s, 1467 m, 1435 s, 1386 m, 1270 vs, 1237 s, 1209 m, $1165 \mathrm{~m}, 1135 \mathrm{vs}, 822 \mathrm{~m}$, and $808 \mathrm{~m}$.

2.1.3. $H_{2}$ L2. An ethanolic solution of pyrrole-2-carboxaldehyde $(11.69 \mathrm{~g}, 123.0 \mathrm{mmol})$ was added to an ethanolic suspension of 2,4-diamino-6-phenyl-1,3,5-triazine (11.52 g, $61.5 \mathrm{mmol})$. The mixture was refluxed in the presence of a few drops of glacial acetic acid for $2 \mathrm{~h}$. The brownish solid formed was filtered from the hot reaction mixture, washed with cold ethanol, and dried in an oven at $80^{\circ} \mathrm{C}$. The yield was $15.8 \mathrm{~g}(68 \%) .{ }^{1} \mathrm{H}-\mathrm{NMR}$ (DMSO- $\left.d_{6}, \delta / \mathrm{ppm}\right)$ was $6.75(b, 4 \mathrm{H})$, 7.43-7.52 $(m, 7 \mathrm{H})$, and 8.23-8.25 $(d, 4 \mathrm{H})$. Selected IR bands $\left(\bar{v} / \mathrm{cm}^{-1}\right)$ were $3292(\mathrm{w}), 3137(\mathrm{w}), 1620(\mathrm{~s}), 1536(\mathrm{~s}), 1389(\mathrm{~s})$, and $1257(\mathrm{w}) \mathrm{cm}^{-1}$.

2.1.4. Trans- $\left[\mathrm{Fe}_{2}\left(\mathrm{CH}_{3} \mathrm{COO}\right)_{4}(\mathrm{L1})_{2}\right]$ (1). $\left[\mathrm{Fe}\left(\mathrm{CH}_{3} \mathrm{COO}\right)_{2}\right]$ $(0.26 \mathrm{~g}, 1.5 \mathrm{mmol})$ and ascorbic acid $(0.43 \mathrm{~g}, 2.44 \mathrm{mmol})$ were dissolved in methanol $\left(50 \mathrm{~cm}^{3}\right)$ at room temperature, forming a black solution. A solution of L1 (1.75 g, $1.5 \mathrm{mmol})$ in chloroform $(10 \mathrm{~mL})$ was gradually added to the black solution. The reaction mixture was stirred at room temperature for $4 \mathrm{~h}$, and then the solvents were evaporated off at room temperature. The dark purple powder formed was successively washed with distilled water, aqueous methanol $(1: 1)$, and methanol and dried in a warm oven for $1 \mathrm{~h}$. The yield was $1.4 \mathrm{~g}$ (70\%). Anal. Calc. for $\mathrm{FeC}_{86} \mathrm{H}_{138} \mathrm{~N}_{2} \mathrm{O}_{8}$ : C, 74.29; H, 10.48; N, 2.01\%. Found: C, 74.96; H, 11.25; N, 1.84\%. Selected IR bands ( $\bar{v} / \mathrm{cm}^{-1}$ ): 2917 (vs), 2849 (vs), 1686 (s), 1672 (m), 1596 (m), 1586 (m), 1511 (s), 1466 (m), 1390 (m), 1272 (vs), 1236 (m), 1165 (m), 1134 (vs), 1069 (m), 1053 (m), 1036 (m), 1018 (m), 1005 (m), 807 (s).

2.1.5. $\left[\mathrm{Fe}_{3}\left(\mathrm{CH}_{3} \mathrm{COO}\right)_{4}\left(\mathrm{H}_{2} \mathrm{O}\right)_{4}(\mathrm{~L} 2)\right] \quad$ (2). $\left[\mathrm{Fe}\left(\mathrm{CH}_{3} \mathrm{COO}\right)_{2}\right]$ $(0.96 \mathrm{~g}, 5.5 \mathrm{mmol})$ was added to an ethanolic suspension of $\mathrm{H}_{2} \mathrm{~L} 2$ ( $1.89 \mathrm{~g}, 5.5 \mathrm{mmol}$ ), followed by about $0.1 \mathrm{~g}$ ascorbic acid as an antioxidant. The mixture was refluxed for $3 \mathrm{~h}$, and the black solid formed was filtered off from the hot reaction mixture, washed with cold ethanol, and dried in an oven at $100^{\circ} \mathrm{C}$. The yield was $2.8 \mathrm{~g}$ (97\%). Anal. Calc. for $\mathrm{Fe}_{3} \mathrm{C}_{27} \mathrm{H}_{29} \mathrm{~N}_{7} \mathrm{O}_{12}$ : C, 39.8; H, 4.1, N, 12.0\%. Found: C, 39.6; $\mathrm{H}, 3.8, \mathrm{~N}, 12.1 \%$. Selected IR bands $\left(\bar{v} / \mathrm{cm}^{-1}\right)$ were $3296(\mathrm{~b})$, 1592 (w), 1532 (s), 1401 (s).

2.2. Computational Method. The first principle code DMol3 from Accelrys Material Studio (version 6.1), which employs the density functional theory (DFT) $[10,11]$, was used in optimization calculation and vibrational analysis. The electron correlation was treated by the spin polarized generalized gradient approximation (GGA) with Perdew, Burke, and Ernzerhof functional (PBE) [12]. The wave functions were represented by using a double-numerical-plus-polarization atomic orbital basis set. The geometry optimization was continued until the changes in energy and atomic displacement were less than $1.0 \times 10^{-5}$ Hartree and $0.005 \AA$, respectively. The maximum force allowed was set at 0.002 Hartree $\AA^{-1}$. Dmol3 generated a Hessian matrix and this was then used to perform a frequency calculation. Harmonic vibrational frequencies were computed by diagonalizing the mass-weighted secondderivative matrix, $F[13]$. The elements of $F$ were obtained by the following equation:

$$
F_{i j}=\frac{1}{\sqrt{m_{i} m_{j}}} \frac{\partial^{2} E}{\partial q_{i} \cdot \partial q_{j}},
$$

where $q_{i}$ and $q_{j}$ refer to the two Cartesian coordinates of atoms $i$ and $j$ and $m_{i}$ and $m_{j}$ are the masses of the respective atoms. The square roots of the eigenvalues of $F$ are the harmonic frequencies and were used to verify the vibrational frequencies of the complexes. These results were then compared to the experimental results.

Dmol3 calculates the vibrational intensities from the atomic polar tensors $(A)$, usually called Bohr effective charges. $A$ is a second derivative energy with respect to the Cartesian coordinates and dipole moments

$$
A_{i, j}=\frac{\partial E}{\partial q_{i} \partial \mu_{i}} .
$$




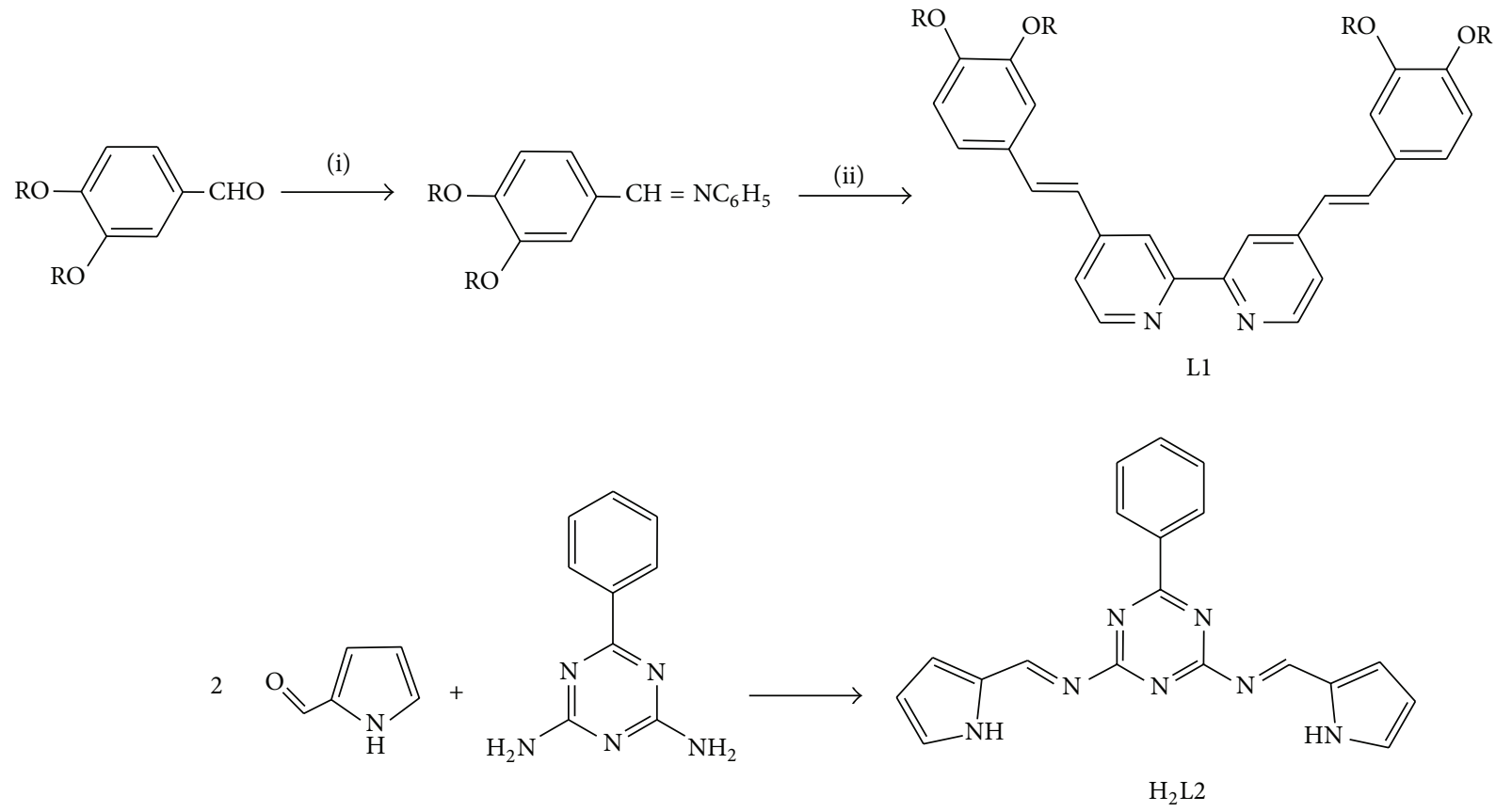

Scheme 1: Steps for the syntheses of $\mathrm{L} 1\left(\mathrm{R}=\mathrm{CH}_{3}\left(\mathrm{CH}_{2}\right)_{13}\right)$ and $\mathrm{H}_{2} \mathrm{~L} 2$. (i) Aniline, p-toluenesulfonic acid, EtOH, RT, $24 \mathrm{~h}$; (ii) 4, $4^{\prime}$-dimethyl$2,2^{\prime}$-bipyridine, $\mathrm{KO}^{t} \mathrm{Bu}, \mathrm{DMF}, 80^{\circ} \mathrm{C}, 2 \mathrm{~h}$.

The intensity of a particular mode was calculated by squaring all transition moments of the mode and expressed in terms of the $A$ matrix and eigenvectors of the mass-weighted Hessian. $F$ is

$$
I_{i}=\left(\sum_{j, k} F_{i, j}^{\prime} A_{j, k}\right)^{2},
$$

where $F^{\prime}$ refers to the eigenvectors of the normal mode, $i$.

\section{Results and Discussion}

3.1. Syntheses and Structural Deduction. The synthetic steps for the preparation of $\mathrm{L} 1$ and $\mathrm{H}_{2} \mathrm{~L} 2$ are shown in Scheme 1 .

The structural formulas of $\mathrm{L} 1$ and $\mathrm{H}_{2} \mathrm{~L} 2$ were ascertained from ${ }^{1} \mathrm{H}-\mathrm{NMR}$ and FTIR spectroscopies (Section 2). From ${ }^{1} \mathrm{H}$-NMR spectroscopy, the $J$ value for the vinylic $\mathrm{H}$ atoms in $\mathrm{L} 1$ was $12 \mathrm{~Hz}$, indicating an $E$ configuration for the ligand (as shown).

The dinuclear complex, trans- $\left[\mathrm{Fe}_{2}\left(\mathrm{CH}_{3} \mathrm{COO}\right)_{4}(\mathrm{~L} 1)_{2}\right](\mathbf{1})$, was obtained as dark purple powder in good yield $(60 \%)$ from the reaction of $\mathrm{Ll}$ with $\left[\mathrm{Fe}\left(\mathrm{CH}_{3} \mathrm{COO}\right)_{2}\right]($ mol ratio $=$ $1: 1)$. The powder was readily soluble in $\mathrm{CH}_{2} \mathrm{Cl}_{2}, \mathrm{CHCl}_{3}$, and toluene. Its structural formula was proposed based on the CHN elemental analytic data and IR spectrum, which showed peaks for $\mathrm{C}=\mathrm{O}$ at $1686 \mathrm{~cm}^{-1}, \bar{v}_{\text {asym }} \mathrm{COO}$ at $1672 \mathrm{~cm}^{-1}$ and $1596 \mathrm{~cm}^{-1}, \bar{v}_{\text {sym }} \mathrm{COO}$ at $1466 \mathrm{~cm}^{-1}$, and peaks for L1. The $\Delta$ values for $\mathrm{CH}_{3} \mathrm{COO}$ ligand $\left(\Delta=\bar{v}_{\text {asym }} \mathrm{COO}-\bar{v}_{\text {sym }} \mathrm{COO}\right)$ were $130 \mathrm{~cm}^{-1}$ and $206 \mathrm{~cm}^{-1}$, which suggest bidentate chelating and monodentate bridging binding modes, respectively [14].
The trinuclear complex, $\left[\mathrm{Fe}_{3}\left(\mathrm{CH}_{3} \mathrm{COO}\right)_{4}\left(\mathrm{H}_{2} \mathrm{O}\right)_{4}(\mathrm{~L} 2)\right]$ (2), was obtained as a black solid from the reaction of $\mathrm{H}_{2} \mathrm{~L} 2$ with $\left[\mathrm{Fe}\left(\mathrm{CH}_{3} \mathrm{COO}\right)_{2}\right](\mathrm{mol}$ ratio $=1: 1)$. It was insoluble in most common organic solvents, except DMSO. As for 1, its structural formula was proposed based on the $\mathrm{CHN}$ elemental analytic data and IR spectrum, which showed peaks for coordinated $\mathrm{H}_{2} \mathrm{O}$ at $3296 \mathrm{~cm}^{-1}, \mathrm{C}=\mathrm{N}$ at $1592 \mathrm{~cm}^{-1}$, $\bar{v}_{\text {asym }} \mathrm{COO}$ at $1532 \mathrm{~cm}^{-1}, \bar{v}_{\text {sym }} \mathrm{COO}$ at $1401 \mathrm{~cm}^{-1}$, and peaks for L2. The $\Delta$ value for $\mathrm{CH}_{3} \mathrm{COO}$ ligand was $131 \mathrm{~cm}^{-1}$, which suggests a chelating binding mode.

The proposed structures for both complexes were then geometry optimized, and then IR spectral simulations were performed within the domain of DFT. After geometrical optimization for 1 , the $\mathrm{Fe}-\mathrm{Fe}$ atomic distance was $3.193 \AA$, while the $\mathrm{Fe}-\mathrm{O}-\mathrm{Fe}$ and $\mathrm{O}-\mathrm{C}-\mathrm{O}$ (for bridging $\mathrm{CH}_{3} \mathrm{COO}$ ) bond angles were $101.9^{\circ}$ and $117.6^{\circ}$, respectively. The $\mathrm{O}-\mathrm{C}-\mathrm{O}$ bond angle for the bridging $\mathrm{CH}_{3} \mathrm{COO}$ is in good agreement with the theoretical value of $120^{\circ}$ for a $s p^{2}$ hybridized carbon.

For IR spectral simulation, the structure for 1 was modelled on both cis- and trans- $\left[\mathrm{Fe}_{2}\left(\mathrm{CH}_{3} \mathrm{COO}\right)_{4}(\mathrm{~L} 3)_{2}\right]$, where L3 $=4,4^{\prime}$-bis(tetramethoxy)styryl-2,2' -bipyridine, and for both monodentate and bidentate bridging $\mathrm{CH}_{3} \mathrm{COO}$. The results (Figure 2) show a better fit for trans- $\left[\mathrm{Fe}_{2}\left(\mathrm{CH}_{3} \mathrm{COO}\right)_{4}(\mathrm{~L} 3)_{2}\right]$ with monodentate bridging $\mathrm{CH}_{3} \mathrm{COO}$ for 1 and good agreement for 2 (Figure 3). Accordingly, we are quite confident that both complexes $\mathbf{1}$ and $\mathbf{2}$ have the proposed structures as shown in Figure 1.

3.2. Electronic Absorption Spectroscopy. The electronic absorption spectrum for 1 in $\mathrm{CHCl}_{3}$ shows a strong singlet metal-to-ligand charge transfer $\left({ }^{1}\right.$ MLCT) peak at $544 \mathrm{~nm}$ $\left(\varepsilon_{\max }=2194 \mathrm{M}^{-1} \mathrm{~cm}^{-1}\right)$ and two weak $d$ - $d$ peaks at $1412 \mathrm{~nm}$ $\left(\varepsilon_{\max }=25.6 \mathrm{M}^{-1} \mathrm{~cm}^{-1}\right)$ and $1755 \mathrm{~nm}\left(\varepsilon_{\max }=25.6 \mathrm{M}^{-1} \mathrm{~cm}^{-1}\right)$. 


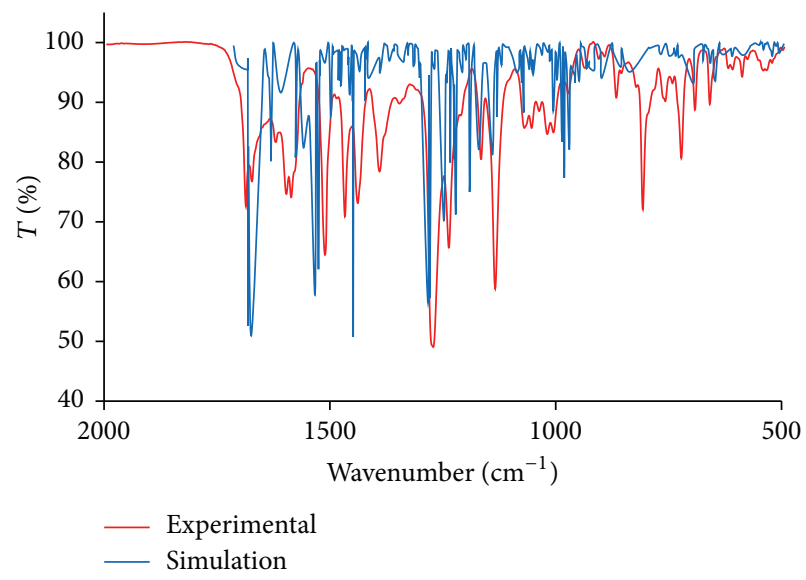

(a)

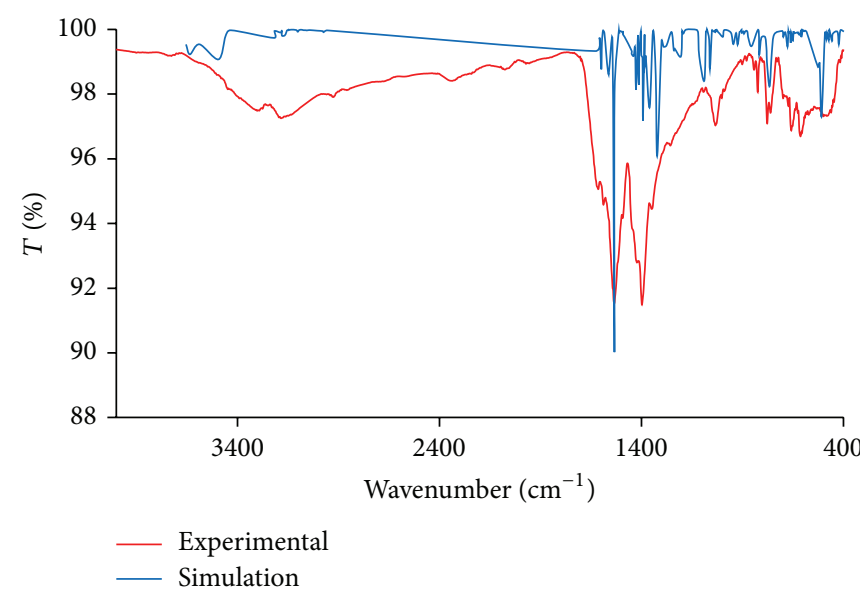

(b)

Figure 2: The experimental and simulated IR spectra for (a) 1 and (b) 2.

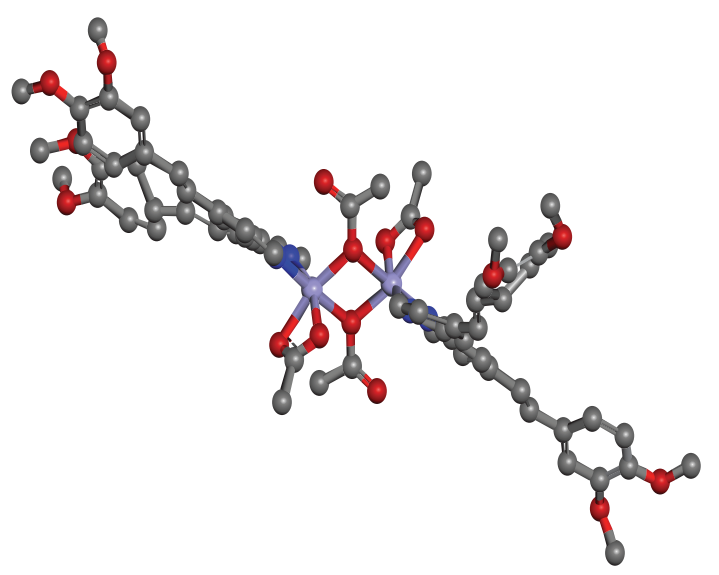

(a)

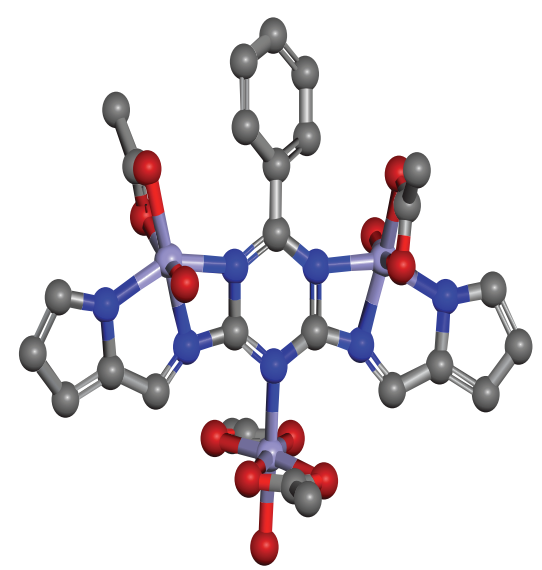

(b)

FIGURE 3: Molecular models for (a) trans- $\left[\mathrm{Fe}_{2}\left(\mathrm{CH}_{3} \mathrm{COO}\right)_{4}(\mathrm{~L} 3]\right)$ and $(\mathrm{b})\left[\mathrm{Fe}_{3}\left(\mathrm{CH}_{3} \mathrm{COO}\right)_{4}\left(\mathrm{H}_{2} \mathrm{O}\right)_{4}(\mathrm{~L} 2)\right](2)$. $\mathrm{H}$ atoms are removed for clarity.

The ${ }^{1}$ MLCT peak is assigned to $t_{2 g} \rightarrow \pi^{*}$ electronic transition for LS Fe(II) [3], while the $d$ - $d$ peaks are assigned to the ${ }^{5} \mathrm{~T}_{2 \mathrm{~g}} \rightarrow{ }^{5} \mathrm{E}_{\mathrm{g}}$ electronic transition for high-spin (HS) $\mathrm{Fe}(\mathrm{II})$. The splitting of the $d-d$ peak for the $\mathrm{HS} \mathrm{Fe}(\mathrm{II})$ may be attributed to a distorted octahedral $\mathrm{N}_{2} \mathrm{O}_{4}$ coordination core at this centre, as a result of weaker $\mathrm{Fe}-\mathrm{N}$ and $\mathrm{Fe}-\mathrm{O}$ bonds [15]. Also found is a $d$-d peak for LS Fe(II), assigned for ${ }^{1} \mathrm{~A}_{1 \mathrm{~g}} \rightarrow{ }^{1} \mathrm{~T}_{1 \mathrm{~g}}$, which appeared as a shoulder on the strong MLCT peak. The spectral data suggest the presence of HS and LS Fe(II) atoms in this complex.

The electronic absorption spectrum for 2 in DMSO shows a broad $d-d$ band at $700 \mathrm{~nm}\left(\varepsilon_{\max }=137 \mathrm{M}^{-1} \mathrm{~cm}^{-1}\right)$ followed by broad overlapping bands at about $340 \mathrm{~nm}(\varepsilon \sim$ $420 \mathrm{M}^{-1} \mathrm{~cm}^{-1}$ ). These bands are assigned to ${ }^{5} \mathrm{~T}_{2 \mathrm{~g}} \rightarrow{ }^{5} \mathrm{E}_{\mathrm{g}}$ for HS Fe(II), and ${ }^{1} \mathrm{~A}_{1 \mathrm{~g}} \rightarrow{ }^{1} \mathrm{~T}_{1 \mathrm{~g}}$ for LS Fe(II) $[4,8], \mathrm{L}^{2-}$, and $\mathrm{CH}_{3} \mathrm{COO}^{-}$intraligand electronic transitions, respectively.

3.3. Magnetic Properties. The temperature-dependence magnetic susceptibilities for $\mathbf{1}$ and $\mathbf{2}$ were measured in the form of $\chi_{M} T$ versus $T$ using the SQUID magnetometer. The plot for $\mathbf{1}$ (Figure 4(a)) shows a good fit between the experimental curve, in the temperature range of about $60 \mathrm{~K}$ to about $250 \mathrm{~K}$, with the theoretical curve obtained using the formula for a symmetrical dinuclear complex [16] and inserting the values of $g=1.9$ and $J=-81.2 \mathrm{~cm}^{-1}$ into the formula

$$
\begin{aligned}
\chi_{M} & =\frac{N g^{2} \beta^{2}}{3 k T} \frac{\sum_{S} S(S+1)(2 S+1) \exp [-E(S) / k T]}{\sum_{S}(2 S+1) \exp [-S / k T]}, \\
E(S) & =-\frac{J}{2} S(S+1) .
\end{aligned}
$$

The $\chi_{M} T$ value for 1 decreased gradually from $3.35 \mathrm{~cm}^{3} \mathrm{~K} \mathrm{~mol}^{-1}$ at $294 \mathrm{~K}$ to $1.12 \mathrm{~cm}^{3} \mathrm{~K} \mathrm{~mol}^{-1}$ at $8.1 \mathrm{~K}$ and then rapidly to about $0.66 \mathrm{~cm}^{3} \mathrm{~K} \mathrm{~mol}^{-1}$ at $2 \mathrm{~K}$ due to the zero-field effect. From this, it can be inferred that $\mathbf{1}$ was made up of $56.8 \%$ HS and $43.2 \% \mathrm{LS} F(\mathrm{II})$ atoms at $294 \mathrm{~K}$, since the expected $\chi_{M} T$ value for a dinuclear octahedral HS Fe(II) complex is $5.9 \mathrm{~cm}^{3} \mathrm{~K} \mathrm{~mol}^{-1}$ at this temperature [16]. It is worth noting that the $g$ value for the complex 


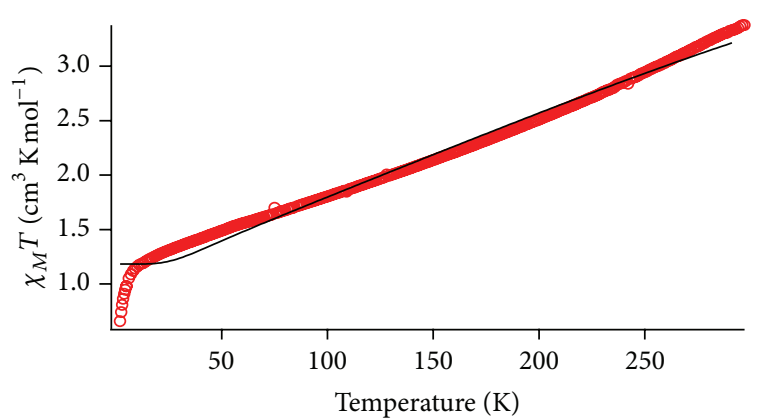

(a)

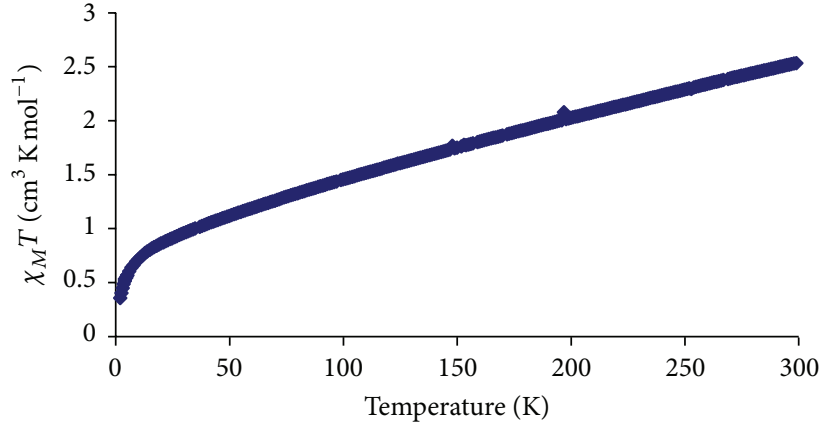

(b)

FIgure 4: Plot of $\chi_{M} T$ versus $T$ for (a) $\mathbf{1}$ (circles = experimental; line = theoretical) and (b) 2.

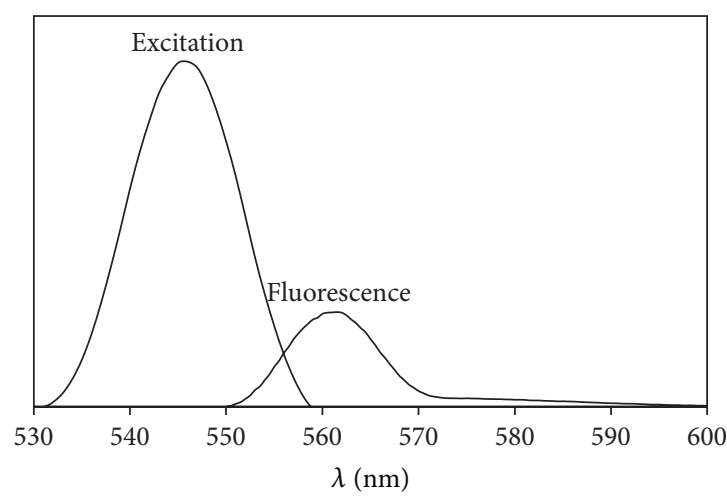

(a)

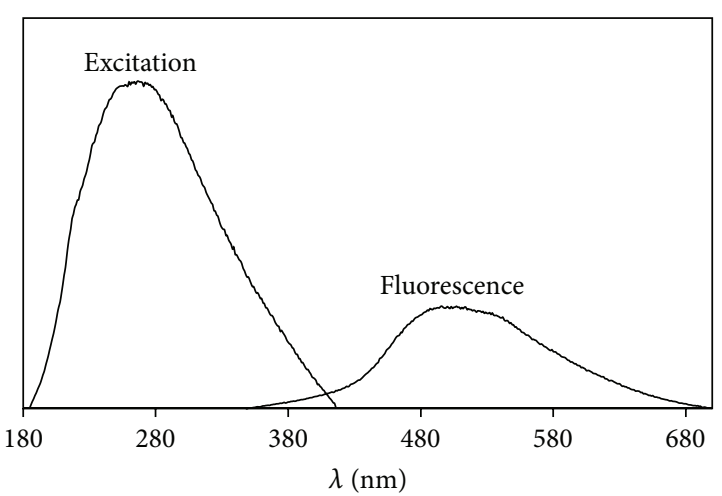

(b)

FIgURE 5: The excitation and fluorescence spectra of (a) $1\left(\lambda_{\text {ex }}=544 \mathrm{~nm}\right)$ and (b) $2\left(\lambda_{\text {ex }}=267 \mathrm{~nm}\right)$.

(1.9) was slightly lower than the theoretical value (2.0023). This suggests an axially distorted octahedral environment, expected at the HS Fe(II) atom. The calculated value for the isotropic interaction parameter $\left(J=-81.2 \mathrm{~cm}^{-1}\right)$ indicates moderate antiferromagnetic interaction between the two $\mathrm{Fe}$ (II) centres, postulated to occur indirectly through the two monoatomic $\mathrm{CH}_{3} \mathrm{COO}$ bridges (superexchange pathway) [17]. Using the calculated $J$ value and its correlation with the bridging angle deduced by Crawford et al., $J\left(\mathrm{~cm}^{-1}\right)=-74 \alpha$ (degrees) $+7270[18]$, the calculated Fe-O-Fe bridging angle $(\alpha)$ of the dimeric complex is $99.3^{\circ}$, which agrees well with the value of $101.9^{\circ}$ obtained from molecular modeling.

A plot of $\chi_{M} T$ versus $T$ (Figure 4(b)) for 2 shows that its $\chi_{M} T$ values decreased gradually from $2.5 \mathrm{~cm}^{3} \mathrm{~K} \mathrm{~mol}^{-1}$ at $300 \mathrm{~K}$ to about $0.9 \mathrm{~cm}^{3} \mathrm{~K} \mathrm{~mol}^{-1}$ at $25 \mathrm{~K}$ and then more abruptly to about $0.4 \mathrm{~cm}^{3} \mathrm{~K} \mathrm{~mol}^{-1}$ at $2 \mathrm{~K}$. From these observations, it can be inferred that the complex was made up of $27.7 \% \mathrm{HS}$ and $72.3 \% \mathrm{LS}$ Fe(II) atoms at $300 \mathrm{~K}$ (the expected $\chi_{M} T$ value for a trinuclear octahedral HS Fe(II) complex at this temperature is $9.03 \mathrm{~cm}^{3} \mathrm{~K} \mathrm{~mol}^{-1}$ ) [16].

The results also indicate that the electronic configuration for HS Fe(II) in both complexes changed to LS on cooling from room temperature.
3.4. Photophysical Studies. Two important parameters for DSSC applications are band gap $(E)$ and excited state lifetime $(\tau)$. Electronic spectroscopies (absorption and photoluminescence) may be used to calculate the optical band gaps $\left(E_{o}\right)$, using the equation $E_{o}=h c / \lambda$, where $h=$ Planck constant $\left(6.626 \times 10^{-34} \mathrm{~J} \mathrm{~s}^{-1}\right), c=$ velocity of light $\left(3.0 \times 10^{8} \mathrm{~m} \mathrm{~s}^{-1}\right)$, and $\lambda=$ absorption edge of charge-transfer (CT) band or emission edge. The calculated value in J was then converted to $\mathrm{eV}$ using the conversion factor 1 Joule $=6.24 \times 10^{18} \mathrm{eV}$. The most simple and direct method used to obtain the $E_{o}$ value is to determine the wavelength at which the extrapolation of the absorption edge crosses the baseline. The $\tau$ value may be calculated from the slope of the fluorescence decay curve and using the equation $F_{t}=F_{o} e^{-t / \tau}\left(F_{t}=\right.$ intensity at time $t, F_{o}=$ intensity at initial time, $t=$ time after absorption).

For 1 , the $E_{o}$ value was $1.9 \mathrm{eV}$ from its absorption spectrum $(\lambda=643 \mathrm{~nm})$. Upon excitation at $544 \mathrm{~nm}$, its fluorescence spectrum shows a weaker peak at $\lambda_{\max } 561 \mathrm{~nm}$ (Figure 5(a)). Hence, the $E_{o}$ value was $2.2 \mathrm{eV}(\lambda=574 \mathrm{~nm})$ and $\tau$ was $0.7 \mathrm{~ns}$. The corresponding values for 2 were $E_{o}$ (absorption) $=3.5 \mathrm{eV}(\lambda=352 \mathrm{~nm}), E_{o}$ (emission after excitation at $267 \mathrm{~nm})=1.8 \mathrm{eV}(\lambda=700 \mathrm{~nm})$ (Figure 5(b)), and $\tau=2.8$ ns.

Three things of interest to note for both complexes are as follows: (a) the intensities of the emission peaks 


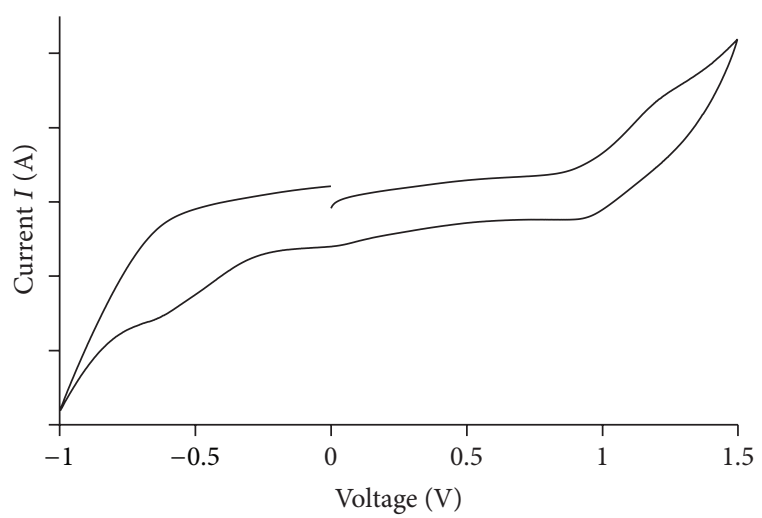

(a)

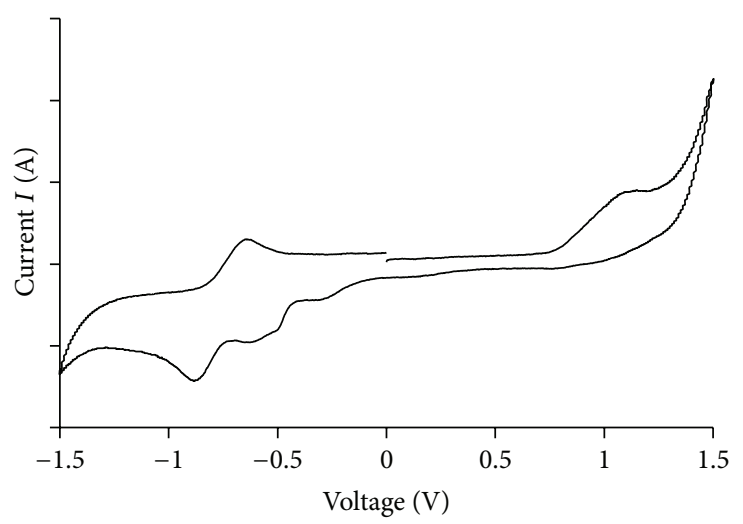

(b)

Figure 6: CV scans for (a) 1 and (b) 2.

were much weaker than the absorption peak. This is due to competitive radiationless process(es); (b) the $E_{o}$ values from the absorption spectrum were lower than those from the fluorescence spectrum. The difference is due to the stabilization of HOMO of the excited Fe(III) complexes formed upon ${ }^{1}$ MLCT transition (a stronger Fe-N bond); and (c) the excited-state lifetime in $\mathbf{1}$ was much shorter than $\mathbf{2}$, which was most likely due to the much higher excitation energy for the latter complex [2]. However, the lifetime for both complexes was significantly shorter than $\left[\mathrm{Ru}\left(2,2^{\prime}\right.\right.$ bipyridine- $4,4^{\prime}$-dicarboxylic acid $\left.)_{2}(\mathrm{NCS})_{2}\right](\tau=50 \mathrm{~ns})$ [5], which are expected due to the low lying ligand field state in Fe(II) complexes. However, their lifetimes are sufficiently long compared to the time required for the injection of an electron into the $\mathrm{TiO}_{2}$ conduction band, reported to occur within femtoseconds [19].

3.5. Electrochemical Studies. The CV scan for 1 (Figure 6) shows an anodic peak at $+1.2 \mathrm{~V}$ and two cathodic peaks at $+0.05 \mathrm{~V}$ and $-0.56 \mathrm{~V}$. These peaks were assigned to the oxidation of $\mathrm{Fe}$ (II) to $\mathrm{Fe}$ (III) and reduction of $\mathrm{Fe}$ (III) to $\mathrm{Fe}$ (II) [3] and $\mathrm{L} 1_{\text {to }} \mathrm{L1}^{-}$[20], respectively. The peaks were weak due to the presence of eight 14-carbon linear alkyl chains acting as an "insulating" layer for the transfer of electrons to/from the electrode surface [21]. The potential separation $(\Delta E)$ between the anodic and cathodic peaks was $1150 \mathrm{mV}$, and the cathodic-to-anodic peak current $\left(I_{\mathrm{pc}} / I_{\mathrm{pa}}\right)$ was close to unity. These indicate a quasireversible redox process and absence of coupled chemical reaction(s), respectively [21]. The formal electrode potential for 1 was $+0.63 \mathrm{~V}$ (versus SCE). This was calculated using the equation $E^{\prime}\left(\mathrm{Fe}^{\mathrm{III}} / \mathrm{Fe}^{\mathrm{II}}\right)=(1 / 2)\left(E_{\mathrm{pf}}+E_{\mathrm{pr}}\right)$, where $E_{\mathrm{pf}}=$ forward peak potential $(+1.2 \mathrm{~V})$ and $E_{\mathrm{pr}}=$ return peak potential $(+0.05 \mathrm{~V})$. This was comparable to the value of $+0.68 \mathrm{~V}$ reported by Ferrere for $\left[\mathrm{Fe}\left(5,5^{\prime}\right.\right.$-dicarboxylic acid$2,2^{\prime}$-bipyridine $\left.\left.)_{2}(\mathrm{CN})_{2}\right]\right)[3]$.

For 2, the CV scan (Figure 6(b)) shows an anodic peak at $+1.1 \mathrm{~V}$ when the electrode potential was increased from $0 \mathrm{~V}$ to $1.5 \mathrm{~V}$, followed by four cathodic peaks at $-0.29 \mathrm{~V}$, $-0.51 \mathrm{~V},-0.62 \mathrm{~V}$, and $-0.88 \mathrm{~V}$ when the electrode potential was reduced from $+1.5 \mathrm{~V}$ to $-1.5 \mathrm{~V}$ and finally an anodic peak at $-0.71 \mathrm{~V}$ when the electrode potential was increased from
$-1.5 \mathrm{~V}$ to $0 \mathrm{~V}$. Firstly, it is noted that the anodic and cathodic peaks for $\mathbf{2}$ were more pronounced than $\mathbf{1}$, consistent with the absence of long alkyl chains attached to $\mathrm{L} 2^{2-}$ ligand. Next, the value of $E\left(\mathrm{Fe}^{\mathrm{III} / \mathrm{II}}\right)$ was $+0.41 \mathrm{~V}$ (versus SCE), which was lower than 1, indicating a more facile oxidation of Fe(II). Finally, other peaks observed may be assigned to ligand-based redox processes.

The electrochemical bandgap $\left(E_{e}\right)$ may be calculated using the relationship, $E_{e}=|\mathrm{HOMO}-\mathrm{LUMO}|$, where $\mathrm{HOMO}$ $=($ onset oxidation peak voltage +4.4$) \mathrm{eV}$ and $\mathrm{LUMO}=$ (onset reduction peak voltage +4.4$)$. Hence $E_{e}=0.83 \mathrm{eV}$ for 1 and $E_{e}=0.69 \mathrm{eV}$ for 2 . The higher $E_{e}$ for $\mathbf{1}$ is consistent with the presence of insulating alkyl groups in this complex.

\section{Conclusions}

Both dimeric (1) and trinuclear (2) complexes have LS and HS $\mathrm{Fe}(\mathrm{II})$ atoms. Complex 1 has a lower optical bandgap, higher electrochemical bandgap, shorter excited state lifetime, and higher formal redox potential than complex 2. Both complexes were potential DSSC materials, but $\mathbf{2}$ is better than $\mathbf{1}$ based on its longer excited lifetime and lower redox potential. It can be concluded from this work that higher nuclearity $\mathrm{Fe}(\mathrm{II})$ complexes are better potential as DSSC materials, while lower MLCT transition energies led to the formation of complexes with lower optical band gaps but also shorter excited state lifetimes, and the presence of insulating long alkyl chains resulted in higher electrochemical band gaps and higher formal redox potentials.

\section{Conflict of Interests}

The authors declare that there is no conflict of interests regarding the publication of this paper.

\section{Acknowledgments}

This research was funded by grants from the Malaysia Ministry of Higher Education (UM.C/625/1/HIR/MOHE/05 and FP031-2013B) and University of Malaya (RP014A-13AET, PV056-2012A and PG023-2013A). The authors also thank 
Professor Duncan W. Bruce from Chemistry Department, York University, York, United Kingdom for his kindness and Professor T. Kuroda-Sowa, Kinki University, Higashi-Osaka, Japan, for his help with SQUID magnetometry.

\section{References}

[1] S. Ferrere and B. A. Gregg, "Photosensitization of $\mathrm{TiO}_{2}$ by $\left[\mathrm{FeII}\left(2,2^{\prime} \text {-bipyridine- } 4,4^{\prime} \text {-dicarboxylic acid }\right)_{2}(\mathrm{CN})_{2}\right]$ : Band Selective electron injection from ultra-short-lived excited states," Journal of the American Chemical Society, vol. 120, pp. 843-844, 1998.

[2] S. Ferrere, "New photosensitizers based upon $\left[\mathrm{Fe}(\mathrm{L})_{2}(\mathrm{CN})_{2}\right]$ and $\left[\mathrm{Fe}(\mathrm{L})_{3}\right](\mathrm{L}=$ substituted 2,2'-bipyridine): yields for the photosensitization of $\mathrm{TiO}_{2}$ and effects on the band selectivity," Chemistry of Materials, vol. 12, pp. 1083-1089, 2000.

[3] S. Ferrere, "New photosensitizers based upon $\left[\mathrm{Fe}^{I I}(\mathrm{~L})_{2}(\mathrm{CN})_{2}\right]$ and $\left[\mathrm{FeIIL}_{3}\right]$, where $\mathrm{L}$ is substituted 2,2' -bipyridine," Inorganica Chimica Acta, vol. 329, pp. 79-92, 2002.

[4] A. Hagfeldt and M. Grätzel, "Molecular photovoltaics," Accounts of Chemical Research, vol. 33, no. 5, pp. 269-277, 2000.

[5] S. Günes and N. S. Sariciftci, "Hybrid solar cells," Inorganica Chimica Acta, vol. 361, no. 3, pp. 581-588, 2008.

[6] N. Sekar and V. Y. Gehlot, "Metal complex dyes for dyesensitized solar cells: recent developments," Resonance, vol. 15, no. 9, pp. 819-831, 2010.

[7] A. Hagfeldt, G. Boschloo, L. Sun, L. Kloo, and H. Pettersson, "Dye-sensitized solar cells," Chemical Reviews, vol. 110, no. 11, pp. 6595-6663, 2010.

[8] P. G. Bomben, K. C. D. Robson, B. D. Koivisto, and C. P. Berlinguette, "Cyclometalated ruthenium chromophores for the dye-sensitized solar cell," Coordination Chemistry Reviews, vol. 256, no. 15-16, pp. 1438-1450, 2012.

[9] R. M. O’Donnell, P. G. Johansson, M. Abrahamsson, and G. J. Meyer, "Excited-state relaxation of ruthenium polypyridyl compounds relevant to dye-sensitized solar cells," Inorganic Chemistry, vol. 52, no. 12, pp. 6839-6848, 2013.

[10] B. Delley, "An all-electron numerical method for solving the local density functional for polyatomic molecules," The Journal of Chemical Physics, vol. 92, no. 1, pp. 508-517, 1990.

[11] B. Delley, "From molecules to solids with the DMol3 approach," Journal of Chemical Physics, vol. 113, no. 18, pp. 7756-7764, 2000.

[12] J. P. Perdew, K. Burke, and M. Ernzerhof, "Generalized gradient approximation made simple," Physical Review Letters, vol. 77, no. 18 , pp. 3865-3868, 1996.

[13] E. B. Wilson, J. C. Decius, and P. C. Cross, Molecular Vibrations, Dover, New York, NY, USA, 1980.

[14] G. B. Deacon and R. J. Phillips, "Relationships between the carbon-oxygen stretching frequencies of carboxylato complexes and the type of carboxylate coordination," Coordination Chemistry Reviews, vol. 33, pp. 227-250, 1980.

[15] M. B. Bushueva, V. P. Krivopalovc, E. B. Nikolaenkovac et al., "Spin crossover complex $\mathrm{FeL}_{2}^{1}\left(\mathrm{ClO}_{4}\right)_{2} \cdot \mathrm{H}_{2} \mathrm{O}\left(\mathrm{L}^{1}=4\right.$-methyl2,6-bis(1H-pyrazol-1-yl)pyrimidine): synthesis and properties," Polyhedron, vol. 43, pp. 81-88, 2012.

[16] O. Kahn, Molecular Magnetism, VCH Publishers, New York, NY, USA, 1993.

[17] M. Yamanaka, H. Uekusa, S. Ohba et al., "Correlation of electron density and spin-exchange interaction in dimeric copper(II) formates, acetates and silanecarboxylates," Acta Crystallographica B, vol. 47, pp. 344-355, 1991.
[18] V. H. Crawford, H. W. Richardson, J. R. Wasson, D. J. Hodgson, and W. E. Hatfield, "Relationship between the singlet-triplet splitting and the $\mathrm{Cu}-\mathrm{O}-\mathrm{Cu}$ bridge angle in hydroxo-bridged copper dimers," Inorganic Chemistry, vol. 15, no. 9, pp. 21072110, 1976.

[19] Y. Tachibana, J. E. Moser, M. Grätzel, D. R. Klug, and J. R. Durrant, "Subpicosecond interfacial charge separation in dyesensitized nanocrystalline titanium dioxide films," Journal of Physical Chemistry, vol. 100, no. 51, pp. 20056-20062, 1996.

[20] M. M. Dîrtu, A. D. Naik, J. Marchand-Brynaert, and Y. Garcia, "Room temperature hysteretic spin transition in $1 \mathrm{D}$ iron(II) coordination polymers," Journal of Physics: Conference, vol. 217, no. 1, Article ID 012085, 2010.

[21] N. Abdullah, Y. Al-Hakem, H. Samsudin, and N. S. A. Tajidi, "Room-temperature magnetic liquid complexes of 2hexyldecanoato ligand with $\mathrm{Cu}(\mathrm{II}), \mathrm{Ni}(\mathrm{II})$ and $\mathrm{Co}(\mathrm{II})$ ions," Asian Journal of Chemistry, vol. 26, no. 4, pp. 987-990, 2014. 


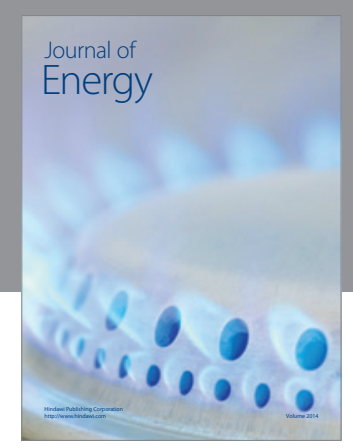

Journal of

Industrial Engineering
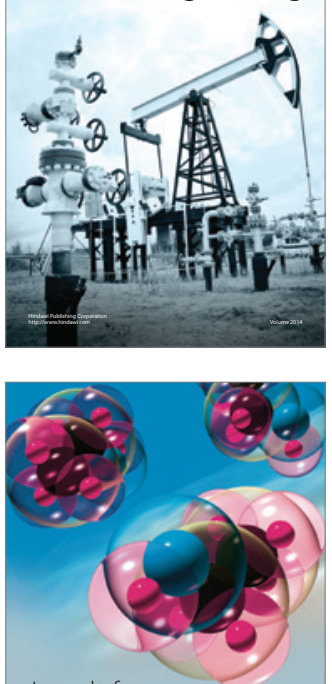

Fuels
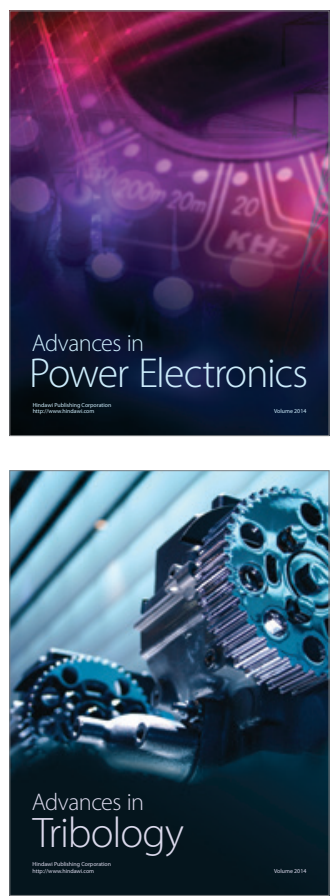

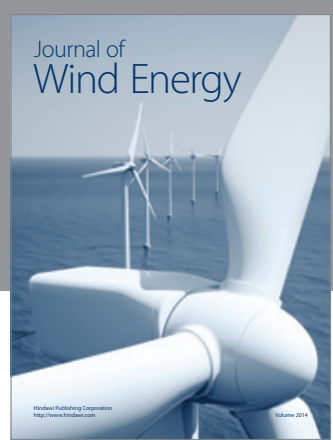

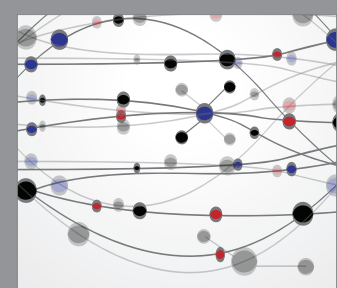

The Scientific World Journal

Submit your manuscripts at http://www.hindawi.com

Journal of

Structures
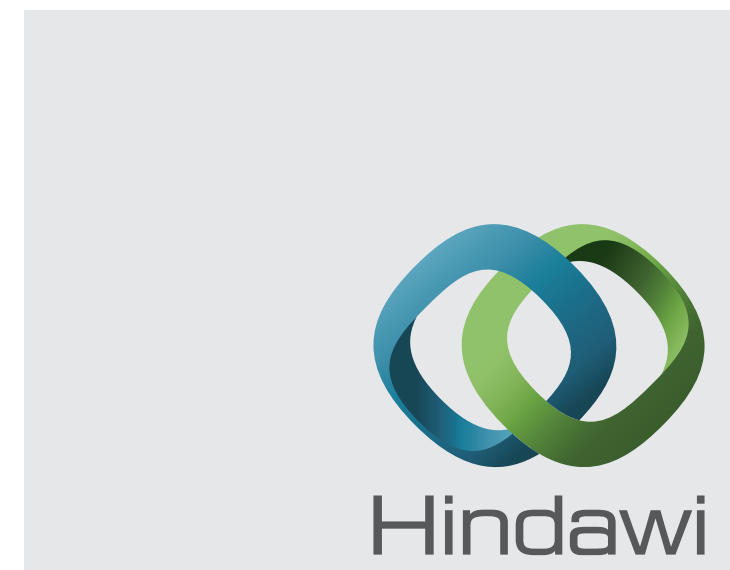

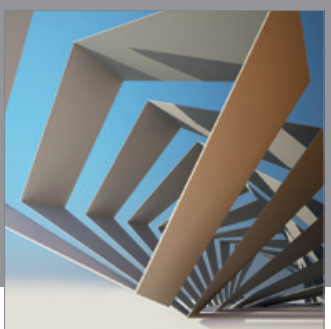

Rotating

Machinery
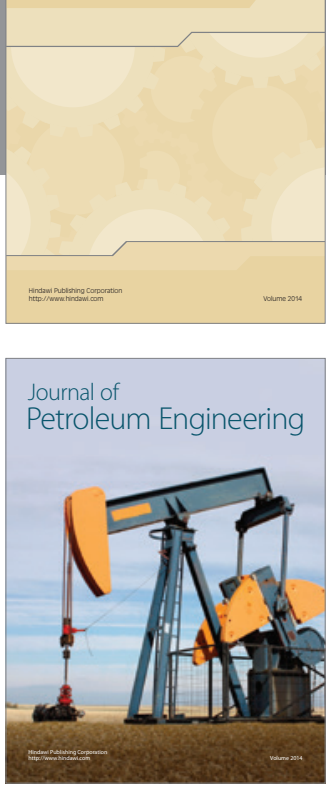

Journal of

Solar Energy
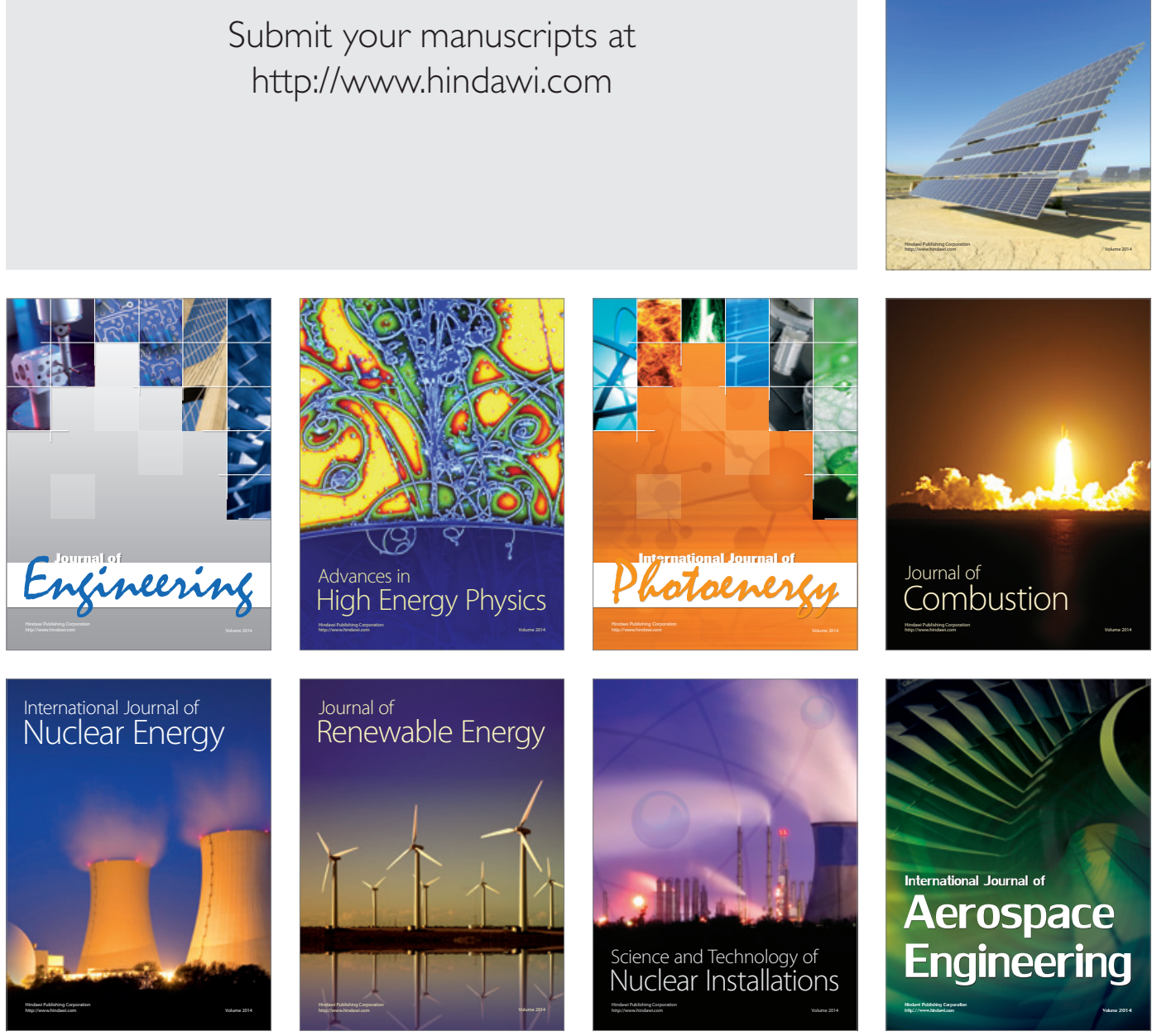